\title{
ANJAY DAN REALISASI PEMAKAIANNYA DALAM KOMENTAR WARGANET DI AKUN INSTAGRAM @NARASINEWSROOM
}

\author{
(Anjay and the Realizations of Its Use in Netizen Comments \\ on@narasinewsroom Instagram Account)
}

\author{
Ai Gumiar \\ Balai Bahasa Provinsi Kalimantan Tengah \\ Jalan Tingang Km 3,5, Palangka Raya, Kalimantan Tengah 73111 \\ Posel: aigumiar@gmail.com
}

(Naskah Diterima 5 Oktober 2020_-Direvisi 30 Oktober 2020-Disetujui 30 Oktober 2020)

\begin{abstract}
The word anjay became a hot topic of conversation among Indonesians at the end of August 2020. Various reports emerged along with the ban on the use of the word of anjay, including on the Instagram account @ narasunewsroom. As an account of news on Instagram, the information on this account is very up to date. The news about the use of the word anjay uploaded to this account. The follower reactions in the comments column are very diverse. The word anjay cannot be separated from the written comments. This paper discusses the speech of warganets that contained the word anjay in Instagram account of @ narasinewsroom. The aims are to provide an overview of the use of the word anjay and its characteristics in speech. Qualitative descriptive method with pragmatic study was used to analyze. The methods used in data collection are observation method and note-taking technique. Geez method used to analyze data. The results show that the form of anjay based on its position in the speech can be at the beginning; middle; end; and combinations of beginning and middle, beginning and end, and middle and end. Meanwhile, based on its communicative values, speeches that contain the word anjay can be divided into five, namely (1) declarative speech; (2) interrogative speech; (3) imperative speech; (4) exclamative speech; and (5) empathic speech.
\end{abstract}

Keywords: pragmatics, anjay, communiative values, utterances, social media language

\begin{abstract}
Abstrak
Kata anjay menjadi ramai dibicarakan masyarakat Indonesia pada akhir bulan Agustus 2020. Berbagai pemberitaan muncul seiring dengan munculnya larangan penggunaan kata anjay, termasuk di akun Instagram @ narasinewsroom. Sebagai akun berita di Instagram, informasiinformasi yang disampaikan di akun ini sangat kekinian. Pemberitaan mengenai penggunaan kata anjay dan problematikanya pun tidak luput dan diunggah di akun tersebut. Reaksi warganet pengikut akun Instagram tersebut di kolom komentar sangat beragam. Kata anjay tidak lepas dari komentar-komentar yang dituliskan. Makalah ini membahas tuturan warganet yang mengandung kata anjay dalam mengomentari unggahan akun Instagram @ narasinewsroom. Tujuannya untuk memberikan gambaran tentang penggunaan kata anjay serta karakteristiknya di dalam tuturan. Metode deskriptif kualitatif dengan kajian pragmatik digunakan untuk menganalisis tuturan tersebut. Metode yang digunakan dalam pengumpulan data adalah metode simak dengan teknik catat. Data dianalisis menggunakan metode agih. Hasilnya menunjukkan bahwa wujud tuturan kata anjay berdasarkan posisinya di dalam tuturan dapat berada di awal, tengah, akhir, dan gabungan awal dan tengah, awal dan akhir, serta tengah dan akhir. Sementara itu, berdasarkan nilai komunikatifnya, tuturan yang mengandung kata anjay dapat dibedakan menjadi lima, yaitu (1) tuturan deklaratif; (2) tuturan interogatif; (3) tuturan imperatif; (4) tuturan eksklamatif; dan (5) tuturan empatik.
\end{abstract}

Kata Kunci: pragmatik, anjay, nilai komunikatif, tuturan, bahasa media sosial 


\section{PENDAHULUAN}

Kata anjay pada akhir Agustus 2020 menjadi perhatian setelah Komisi Nasional Pelindungan Anak (Komnas PA) mengeluarkan pernyataan yang kontroversial terkait dengan larangan penggunaan kata anjay untuk berkomunikasi. Kata anjay dinilai berpotensi menimbulkan kekerasan verbal saat dituturkan sehingga penggunaannya perlu dihentikan.

Berdasarkan informasi yang dikutip dari Kompas.com, Arist Merdeka Sirait, Ketua Komnas PA menyampaikan bahwa pengguna kata anjay yang berkonotasi negatif berpotensi untuk ditindak secara pidana. Komnas PA mendapatkan pengaduan atas keresahan masyarakat terhadap penggunaan kata anjay. Lutfi Agizal diketahui sebagai pihak yang menyampaikan keresahannya tersebut kepada Komnas PA. Menurutnya, kata anjay dinilai memiliki konotasi negatif. Kata tersebut cenderung digunakan dengan maksud merundung atau merendahkan.

Lutfi Agizal kerap mengunggah kontenkonten yang membahas tema tertentu di akun media sosialnya, seperti di Youtube dan Instagram. Dalam video yang dibuat dan diunggah di akun Youtube pribadinya yang dapat diakses melalui tautan https://www.youtube.com/watch? $v=9 d D K C$ LASxek, Lutfi mengangkat isu tentang penggunaan kata anjay. Dalam video yang bertajuk "NGOMONG ANJ*Y BISA MERUSAK MORAL BANGSA" dan disertai tagar EdukasiLihatAjaDulu, StopAnj*ay, dan Viral, Lutfi menyampaikan temuannya tentang kata anjay. Dalam video yang berdurasi 30 menit dan 24 detik tersebut, Lutfi berbincang dengan seorang narasumber yang bernama Dr. Tomi Yuniawan, M.Hum., dosen Universitas Negeri Semarang.

Dr. Tomi Yuniawan, M.Hum. menjelaskan bahwa kata anjay merupakan fenomena bahasa yang terjadi sebagai bentuk ekspresi penuturnya dalam berinteraksi. Masyarakat Indonesia yang heterogen menyebabkan bahasa yang hidup pun menjadi heterogen atau bervariasi. Variasi bahasa ini terus berkembang seiring dengan perkembangan masyarakat penuturnya. Keheterogenan masyarakat itu terjadi karena berbagai aspek, baik usia, pendidikan, etnis, maupun status sosial. Dalam kaitannya dengan penggunaan bahasa, para penutur bahasa perlu bijak dalam berbahasa.

Kata anjay banyak digunakan oleh generasi muda, khususnya generasi milenial dalam berkomunikasi sehari-hari. Tidak hanya dalam kehidupan nyata, dalam konten-konten yang beredar di media sosial (dunia maya) pun, banyak pembuat konten, seperti publik figur, yang menggunakan kata anjay dalam konten-konten yang mereka buat. Penggunaan kata tersebut dalam bertutur kemudian diikuti oleh pengikut mereka (warganet), mulai dari orang dewasa sampai anak-anak. Kata anjay menjadi lekat dalam ingatan warganet sehingga terbawa dalam tuturan sehari-hari.

Anak-anak sebagai bagian dari ekosistem masyarakat yang belum mampu menyaring informasi yang diperolehnya memiliki kemungkinan paling tinggi terpapar perkembangan bahasa. Oleh karena itu, anak dianggap perlu mendapatkan pelindungan, khususnya dari orang tuanya dan Komnas PA. Oleh karena itu, Komnas PA melalui Arist Merdeka Sirait menyampaikan dukungan untuk menghentikan penggunaan kata anjay tersebut dalam berkomunikasi.

Larangan penggunaan kata anjay tersebut menimbulkan pro dan kontra masyarakat, khususnya warganet. Para pengguna media sosial tersebut pada umumnya tidak menerima keputusan yang dikeluarkan Komnas PA tersebut. Beragam argumen disampaikan warganet terhadap hal tersebut, baik di akun media sosial milik pribadi mereka maupun di akun lain yang membahas isu tersebut.

Di media-media sosial, seperti Twitter, Youtube, dan Instagram, informasi mengenai larangan penggunaan kata anjay sempat menjadi hal yang paling banyak dibicarakan. Dikutip dari Kompasiana.com, kata anjay ditulis lebih dari 213.000 kali di Twitter hingga 31 Agustus 2020. Fenomena ini mengundang ketertarikan tersendiri bagi 
berbagai pihak, terutama bagi pemerhati bahasa.

Beragam tanggapan disampaikan para pakar bahasa terkait dengan korelasi makna kata anjay dengan konteks pemakaiannya dalam tuturan. Kata anjay merupakan kosakata ragam nonformal yang digunakan dalam bahasa pergaulan, khususnya generasi muda di dunia maya. Keberadaan kata anjay ini lekat dengan ragam bahasa pergaulan. Menurut Kridalaksana (2008, p. 25), ragam gaul termasuk ragam nonstandar bahasa Indonesia yang diperkenalkan oleh generasi muda. Ragam ini cenderung memanfaatkan sintaksis dan morfologi bahasa Indonesia.

Di Instagram, larangan mengenai penggunaan kata anjay yang dikeluarkan oleh Komisi Nasional Pelindungan Anak ini tidak luput dari pemberitaan akun @ narasinewsroom. Akun tersebut diikuti 346.000 pengguna Instagram hingga 6 September 2020. Informasi dan berita yang disampaikan di akun @ narasinewsroom dikemas dengan unik dan menarik. Meskipun begitu, isi atau informasi yang disampaikan tetap dibahas dengan mengena pada inti permasalahan dan menjangkau bagian-bagian vital isu yang diangkat. Berita disajikan dengan padat, jelas, dan menarik dalam video berdurasi singkat.

Informasi terkait dengan kontroversi penggunaan kata anjay juga tidak luput dari pemberitaan@narasinewsroom. Pengelola akun tersebut mengunggah video berdurasi singkat yang bertajuk "Ketika Berucap Anjay Bisa Berujung Pidana." Video yang diunggah pada 2 September 2020 tersebut berisi takarir (caption) sebagai berikut.

"Ngomong "Anjay" Bisa Berujung Pidana? Hayo, siapa yang masih sering mengucap kata "anjay"? Hati-hati, lho, salah-salah nanti bisa dilaporkan dan ditindak secara pidana. Begitu kira-kira kata yang lagi diributkan hari-hari ini. Kata itu jadi perbincangan lantaran Komisi Nasional Perlindungan Anak (Komnas PA) merilis surat edaran penghentian penggunaan kata "anjay".

Alasannya kata "Anjay" yang digunakan dalam kalimat bermakna merendahkan martabat seseorang bisa termasuk dalam kekerasan verbal."

Lalu, apakah penggunaan kata anjay dalam berkomunikasi, khususnya di media sosial, dapat menimbulkan makna yang berkonotasi merendahkan atau menjatuhkan? Untuk membuktikan hal tersebut, perlu dilakukan kajian tentang penggunaan kata anjay di media sosial dalam kaitannya dengan bidang ilmu pragmatik. Dalam hal ini, tanggapan berupa komentar yang diberikan warganet pengikut akun@narasinewsroom terhadap unggahan di akun tersebut akan menjadi fokus pembahasan.

Pemakaian kata anjay dalam kolom komentar yang disampaikan warganet sangat beragam. Warganet tidak hanya memberikan komentar terhadap unggahan tersebut, tetapi juga menulis tanggapan yang berupa realisasi penggunaan kata anjay secara langsung. Hal ini menimbulkan ketertarikan tersendiri mengingat komentar dan tanggapan tersebut dapat dijadikan sebagai bahan untuk menyelisik realitas penggunaan kata anjay dalam tuturan, khususnya di media sosial. Dengan demikian, tidak hanya mengetahui pro atau kontra warganet terhadap larangan penggunaan kata anjay, kajian ini sekaligus dapat melihat penggunaan kata anjay dalam konteks tertentu.

Pragmatik sebagai bagian dari ilmu linguistik menjadi sangat potensial untuk mendukung perkembangan bidang ilmu linguistik ini. Cruse dalam Cummings (2007, p. 2) menyatakan bahwa pragmatik dapat dianggap berurusan dengan aspek-aspek informasi (dalam pengertian yang paling luas) yang disampaikan melalui bahasa yang (a) tidak dikodekan oleh konvensi yang diterima secara umum dalam bentuk-bentuk linguistik yang digunakan, tetapi yang (b) juga muncul secara alamiah dari dan tergantung dari makna-makna yang dikodekan secara konvensional dengan konteks tempat penggunaan bentuk-bentuk tersebut (penekanan ditambahkan). Pragmatik menjadi 
sangat lekat dan dekat dengan kehidupan sehari-hari. Objek kajiannya semakin beragam seiring dengan fenomena kebahasaan yang terjadi di masyarakat.

Tuturan warganet dengan kata anjay di dalamnya juga menunjukkan fenomena kebahasaan tersendiri, terutama setelah adanya pro dan kontra masyarakat sebagai penuturnya. Dalam bidang ilmu pragmatik, tuturan tersebut dapat dianalisis berdasarkan aspek situasi tuturnya. Wijana menyampaikan bahwa aspek situasi tutur ada lima, yaitu (1) penutur dan lawan tutur, (2) konteks tuturan, (3) tujuan tuturan, (4) tuturan sebagai aktivitas, dan (5) tuturan sebagai produk tindak verbal (Nurlina, 2019, p. 36). Dalam kajian ini, penutur yang dimaksud adalah warganet pengikut akun Instagram @narasinewsroom. Mitra tutur yang dimaksud mencakup pengelola akun Instagram @ narasinewsroom, Lutfi Agizal, Komnas PA, dan masyarakat umum. Konteks tuturan ini adalah pengelola akun@narasinewsroom mengunggah video yang berisi informasi tentang problematika larangan penggunaan kata anjay yang disampaikan oleh Lutfi Agizal dan Komnas PA.

Kolom komentar di Instagram menjadi tempat berisi data-data kebahasaan yang menarik untuk dianalisis. Komentar yang ditulis warganet sering kali ditulis dengan spontan sehingga memuat informasi kebahasaan yang tidak direkayasa. Penggunaan kata anjay di dalam komentarkomentar di akun@narasinewsroom dapat menjadi referensi penggunaan kata tersebut dalam bertutur secara apa adanya. Dengan demikian, dapat diketahui perilaku kata anjay tersebut di dalam tuturan.

Moeliono dalam Rahardi menyatakan bahwa apabila didasarkan pada nilai komunikatifnya, kalimat atau tuturan dalam bahasa Indonesia dapat dibedakan menjadi lima, yakni (1) kalimat deklaratif, (2) kalimat imperatif, (3) kalimat interogatif, (4) kalimat eksklamatif, dan (5) kalimat empatik. Komentar-komentar yang disampaikan warganet sebagai tanggapan atas unggahan video tentang problematika penggunaan kata anjay di akun Instagram @narasinewsroom dapat berwujud tuturan-tuturan yang mengandung nilai komunikatif tersebut (Rahardi, 2005, p. 2).

Permasalahan yang menjadi pokok bahasan dalam penelitian ini dirumuskan menjadi sebagai berikut. Pertama, bagaimana wujud penggunaan kata anjay yang ditulis warganet pengikut @narasinewsroom di kolom komentar dalam menanggapi berita larangan penggunaan kata anjay oleh Komnas PA? Kedua, bagaimana nilai komunikatif tuturan yang mengandung kata anjay yang ditulis warganet pengikut @narasinewsroom di kolom komentar dalam menanggapi berita larangan penggunaan kata anjay oleh Komnas PA?

Berdasarkan rumusan masalah tersebut, tujuan penelitian ini adalah sebagai berikut. Pertama, mendeskripsikan wujud penggunaan kata anjay yang ditulis warganet pengikut @ narasinewsroom di kolom komentar dalam menanggapi berita larangan penggunaan kata anjay oleh Komnas PA. Kedua, mendeskripsikan nilai komunikatif tuturan yang mengandung kata anjay yang ditulis warganet pengikut @narasinewsroom di kolom komentar dalam menanggapi berita larangan penggunaan kata anjay oleh Komnas PA.

Penelitian ini diharapkan dapat memberikan manfaat, baik secara teoretis maupun praktis. Secara teoretis, penelitian diharapkan dapat menambah dan memperkaya khazanah keilmuan, terutama dalam bidang pragmatik dan sosiolinguistik serta menjadi sumber informasi baru mengenai hakikat penggunaan kata anjay dalam tuturan seharihari. Secara praktis, penelitian ini diharapkan dapat memberikan manfaat dan menambah wawasan para pemerhati bahasa dalam mengkaji penggunaan kata-kata bahasa Indonesia, termasuk slang.

Penelitian terhadap komentar warganet di akun Instagram pernah dilakukan Kusmanto, dkk. dengan judul "Realisasi Tindak Kesantunan Berbahasa pada Komentar Akun Istagram Jokowi: Studi Politikopragmatik". Dalam penelitian tersebut 
ditemukan strategi kesantunan berbahasa yang digunakan warganet dalam berkomentar pada akun Instagram Jokowi. Ada dua strategi kesantunan yang digunakan warganet, yaitu strategi kesantunan positif dan strategi kesantunan negatif. Strategi kesantunan positif direalisasikan dengan wujud memberi perhatian, menunjukkan sikap dalam berkomunikasi, mengintensifkan perhatian penutur dengan cara mendramatisasi peristiwa dan fakta, memperhatikan keinginan mitra tutur, memberikan janji, dan menggunakan lelucon. Sementara itu, strategi kesantunan negatif direalisasikan dalam wujud meminta maaf, menunjukkan sikap pesimistis, dan menggunakan bentuk impersonal (Kusmanto, 2019).

Husa pernah melakukan penelitian dengan judul "Bentuk dan Pemakaian Slang pada Media Sosial Line (Akun Batavia Undip)". Dalam penelitiannya, Husa menjabarkan bentuk serta arti dari slang Jakarta serta mendeskripsikan pola pembentukan slang Jakarta. Berdasarkan hasil penelitiannya, ditemukan dua bentuk slang, yaitu bentuk dasar dan bentuk turunan. Sementara itu, pola pembentukan slang terdiri atas pola pembentukan bedasarkan perubahan struktur fonologis, berdasarkan proses abreviasi, berdasarkan pembentukan kata baru, dan berdasarkan kata pelesetan. Di antara bentuk slang yang diteliti, ditemukan anjay sebagai satu di antara kosakata slang (Husa, 2017).

Listeani dalam penelitiannya yang berjudul "Penggunaan Kosakata Bahasa Indonesia pada Generasi Millenial" menemukan kata anjay sebagai kosakata bahasa yang digunakan generasi milenial. Husna meneliti aspek bahasa tulis di grup WhatsApp Pramuka Libelta dan Flascheetos SMAN 15 Kabupaten Tangerang kelas XI. Berdasarkan hasil penelitiannya, ditemukan 102 kosakata bahasa generasi milenial. Kata anjay termasuk lima besar yang paling sering dituturkan (Listeani, 2020).

Penelitian tentang bahasa gaul pernah dilakukan oleh Setyawati dengan judul "Pemakaian Bahasa Gaul dalam Komunikasi di Jejaring Sosial". Berdasarkan penelitian yang dilakukannya, ditemukan wujud pemakaian bahasa gaul dalam komunikasi di jejaring sosial berupa kata yang tidak beraturan dan tidak dirumuskan; cenderung menyingkat kata; dan menggunakan partikel. Selain itu, Setyawati menjelaskan bahwa faktor yang melatarbelakangi pemakaian bahasa gaul di jejaring sosial adalah untuk mempererat hubungan, mencari bentuk jati diri, mengungkapkan ekspresi diri; menyampaikan hal-hal yang dianggap tertutup bagi kelompok usia lain atau agar pihak lain tidak dapat mengetahui apa yang sedang dibicarakan; dan untuk maksud penyembunyian atau kejenakaan. Kata anjay sebagai bagian dari bahasa gaul di jejaring sosial memungkinkan untuk memenuhi salah satu kriteria pemakaiannya, seperti sebagai ungkapan ekspresi diri penuturnya (Setyawati, 2014).

Khoirurrohman dan Abdan pada 2020 melakukan penelitian dengan judul "Analisis Pemakaian Variasi Bahasa Slang pada Remaja Desa Kalinusu: Kajian Sosiolinguistik". Penelitian tersebut menemukan 35 kosakata variasi bahasa slang yang digunakan oleh remaja di Dukuh Kemiri, Desa Kalinusu. Satu di antara kosakata tersebut adalah anjay. Dalam penelitian tersebut disampaikan bahwa anjay termasuk variasi bahasa slang pengganti bentuk kata seruan dari wow. Umumnya, kata anjay digunakan oleh kaum muda. Dalam tataran kalimat, anjay tidak memiliki kelengkapan unsur gramatikal (Khoirurrohman \& Abdan, 2020).

Dalam penelitian yang membahas kosakata bahasa pergaulan, penelitian bahasa slang telah beberapa kali dilakukan. Akan tetapi, penelitian tentang realisasi penggunaan kata anjay secara spesifik dalam tuturan warganet belum banyak dilakukan, apalagi dalam komentar pengikut akun Intagram @narasinewsroom berdasarkan perilakunya dalam tuturan dan nilai komunikatifnya. Dengan demikin, masih banyak potensi temuan tentang keunikan penggunaan kata anjay dalam tuturan di media sosial. Hal ini terjadi karena media sosial sebagai hasil 
perkembangan teknologi, selalu menjadi alat yang memungkinkan munculnya fenomena kebahasaan yang baru. Oleh karena itu, pembahasan mengenai hal ini masih perlu dilakukan untuk memperkaya khazanah pengetahuan linguistik, khususnya dalam bidang pragmatik dan sosiolinguistik.

\section{METODE PENELITIAN}

Metode penyajian data yang digunakan dalam penelitian ini adalah metode deskriptif kualitatif. Djajasudarma menyampaikan bahwa metode deskriptif merupakan metode yang bertujuan membuat deskripsi, yaitu membuat lukisan atau gambaran secara sistematis, faktual, dan akurat mengenai data yang diteliti (Djajasudarma, 2009).

Makalah ini disajikan secara sistematis berdasarkan hasil analisis terhadap data yang berupa tuturan warganet dalam komentar di akun Instagram @ narasinewsroom. Analisis dilakukan berdasarkan identifikasi wujud dan nilai komunikatif kata anjay dalam tuturan. Kefaktualan dan keakuratan menjadi kekhasan dalam penelitian ini.

Metode pengumpulan data yang digunakan dalam penelitian ini adalah metode simak dengan teknik catat. Sudaryanto menyatakan bahwa disebut "metode simak" atau "penyimakan" karena memang berupa penyimakan: dilakukan dengan menyimak, yaitu menyimak penggunaan bahasa (Sudaryanto, 2015, p. 203). Data yang digunakan adalah komentar warganet di akun@narasinewsroom yang memuat kata anjay yang ditulis sejak 2 September 2020 sampai dengan 8 September 2020. Data disimak satu per satu agar diketahui adanya kata anjay dalam tuturan tersebut. Dari 1.298 komentar yang ditulis warganet hingga 8 September 2020, dipilih 100 komentar sebagai data primer. Teknik catat digunakan untuk mengumpulkan data tersebut. Teknik ini dilakukan dengan cara melakukan pencatatan terhadap data yang diperoleh.
Dalam hal ini, pencatatan dilakukan dengan menyalin dan menempel komentar warganet dari Instagram ke dalam dokumen berformat Microsoft Word. Setiap komentar diberi identitas untuk memudahkan dalam melakukan pengidentifikasian. Struktur identitas tersebut adalah sebagai berikut. (@xx/xx/xx/xx)

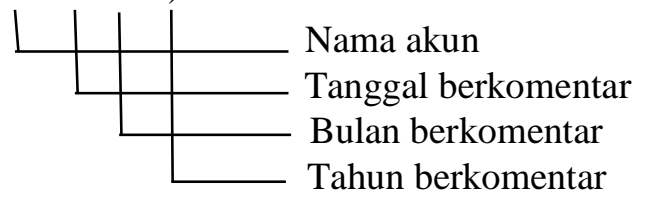

Metode analisis data yang digunakan dalam penelitian ini adalah metode padan intralingual (Mahsun, 2017) dan padan pragmatis (Sudaryanto, 2015). Komentar warganet di akun Instagram @ narasinewsroom yang memuat kata anjay diidentifikasi menggunakan metode padan intralingual berdasarkan wujud dan nilai komunikatifnya dalam tuturan. Hal ini sesuai dengan teori tentang nilai komunikatif tuturan yang disampaikan oleh Moeliono dalam Rahardi. Komentar warganet diidentifikasi sebagai tuturan deklaratif, imperatif, interogatif, eksklamatif, atau empatik.

Dalam melakukan analisis, penulis menguraikan data menjadi komentarkomentar terpisah, kemudian menyajikannya dalam bentuk tabel dan angka. Penelitian-penelitian terdahulu yang berkaitan dengan realisasi penggunaan kata anjay, kosakata slang, bahasa di media sosial, dan bahasa yang digunakan generasi muda dijadikan sebagai rujukan dalam menganalisis data. Dengan adanya rujukan, dasar menganalisis yang akan dilakukan menjadi lebih jelas.

Teknik penyajian data yang digunakan lebih menekankan pada teknik kualitatif. Hasil penelitian ini lebih mementingkan aspek kualitas daripada kuantitas. Hasil analisis yang sudah diklasifikasikan disajikan dalam bentuk deskripsi sesuai dengan data sebenarnya yang diperoleh dari komentar warganet di akunInstagram @narasinewsroom. 


\section{PEMBAHASAN}

\section{Wujud Tuturan yang Memuat Kata Anjay dalam Komentar di Akun Instagram @narasinewsroom}

Komentar yang ditulis warganet di kolom komentar Instagram @ narasinewsroom merupakan tuturan yang berupa kata, frasa, klausa, dan kalimat yang memuat kata anjay di dalamnya. Kata anjay yang berada di dalam tuturan tersebut memiliki wujud yang berbeda. Perbedaan tersebut dapat diidentifikasi berdasarkan letak atau posisinya serta nilai komunikatifnya di dalam tuturan.

Tuturan yang memuat kata anjay memiliki empat bentuk berdasarkan posisinya, yaitu di awal tuturan, di akhir tuturan, di tengah tuturan, serta gabungan di awal, tengah, atau akhir tuturan. Berikut tabel frekuensi kemunculannya.

\section{Tabel 1}

Posisi Pemakaian Kata Anjay dalam Tuturan

\begin{tabular}{lll}
\hline No & $\begin{array}{l}\text { Posisi Kata } \\
\text { Anjay dalam } \\
\text { Tuturan }\end{array}$ & $\begin{array}{l}\text { Frekuensi } \\
\text { Kemunculan }\end{array}$ \\
\hline 1 & Awal & 31 \\
\hline 2 & Tengah & 45 \\
\hline 3 & Akhir & 17 \\
\hline 4 & Gabungan & 7 \\
\hline
\end{tabular}

a. Di Awal Tuturan

Dalam komentar di akun @ narasinewsroom, kata anjay digunakan di awal tuturan dengan struktur yang beragam. Berikut contoh pemakaian kata anjay di awal tuturan yang dimaksud.

(1)Anjayyy hanya pengalihan isu, tetap kawal kebakaran gedung kejaksaan bro 행 (@xhafidhx/02/09/2020)

(2)Anjay, bentar lagi aku dipenjara. (@imlipky/02/09/2020)

(3) ANJAY TANGKAP AKU (@ajixg/02/09/2020)

(4)"anjay lu" gaboleh dong? (@ sandratangkulung/03/09/2020)
(5)Anjay? Anjing naik bajay? cc: @ decdecky

(@mellaoi/03/09/2020)

Pada contoh (1) sampai dengan (5), kata anjay berada di awal tuturan. Anjay mendahului kata-kata selanjutnya di dalam tuturan.

b. Di Akhir Tuturan

Kata anjay dalam tuturan yang berupa komentar di akun Instagram @ narasinewsroom digunakan di akhir tuturan. Anjay ditulis setelah kata-kata atau tuturan yang disampaikan. Berikut contoh pemakaian kata anjay di akhir tuturan dalam komentar di akun Instagram @narasinewsroom.

(6) Kasian polisi tugasnya nambah, udh pusing ngurusin koruptor sampe maling daleman, eh ditambah ngurusin orang $\mathrm{yg}$ ngomong ANJAY किस्क (@ kikissikikiss/02/09/2020)

(7) HALU TINGKAT ANJAYYYYYYY (@ an.gel1236/02/09/2020)

(8) Alangkah lucunya negeri ini, seurgent itu kah sampe seindonesia ngurusin ini..banyak hal yg lebih penting ga sih...anjaayyy (@khairil_abang/02/09/2020)

(9) Dengan adanya press rilis, secara langsung juga memviralkan dan mengajarkan kata Anjay (2):(@ allamin07/02/09/2020)

(10) Ko ngatur sih, ngasih makan gua aja kagak, anjay (@adamconello2019/03/09/2020)

Pada data (6), (7), (8), (9), dan (10), kata anjay digunakan di akhir tuturan.

c. Di Tengah Tuturan

Anjay ditemukan di tengah tuturan. Artinya, anjay diapit oleh kata-kata atau tuturan lain yang disampaikan oleh penutur (warganet) dalam komentar di 
akun Instagram @narasinewsroom. Berikut contoh penggunaan kata anjay di tengah tuturan.

(11) Jepang sudah progres dengan mengembangkan mobil terbang, dan anak anak Indonesia masi ribut masalah kata "anj*y" wkwk kalian hebat lanjutkan (2):(muhamadrizky98/02/09/2020)

(12) Dalam bahasa sanksekerta anjay berarti tak terkalahkan (@ miftazulfa/02/09/2020)

(13) Walaupun ANJAY itu pelesetan dari ANJING, gk sampailah masuk rana pidana. Cukup GAK SOPAN saja (maftuhinwahib/02/09/2020)

(14) Kenapa enggak dari duluu dulu dipermasalakan kata Anjay, atau Anjir kanapa baru baru ini. Dan lagi ada lagi kata baru yaitu Anjim... (@ anwaradi92/02/09/2020)

(15) Dimana kasarnya, dimana ngrendahinnya...bisakah kata anjay dipake untuk bahasa keras,menrt saya anjay itu lebih ke bentuk kagum akan sesuatu,dibanding merendahkan...trus skrng karna ada yg mempemaslahkan, maka jdilah viral..semakin bnyak yg memakainya...tiap thun anak muda psti punya trend sendiri dlm berbicara,kata ini pun lama" akan dilupakan...dan diganti dngn yg bru...kenapa si harus diributkan...:(2)(2)(2)(-): (@verione_the_ground/02/09/20 20)

Pada data (11), (12), (13), (14), dan (15), kata anjay diapit oleh kata lain di sisi kanan dan kirinya. Artinya, ada kata lain yang mendahului kata anjay dan setelah kata anjay.

d. Gabungan di Awal, Tengah, atau Akhir Tuturan

Kata anjay ditemukan dengan perilaku lain di dalam tuturan warganet dalam berkomentar di akun Instagram @ narasinewsroom. Kata anjay digunakan di awal dan di tengah tuturan, di tengah dan di akhir tuturan, serta di awal dan di akhir tuturan sekaligus. Berikut wujud pemakaian kata anjay tersebut.

(16) Kasian yg namanya anjay kesumadiningrat..anjay

pratama...dan anjay 2 yg

lain...seolah2 sudah tidak ada kasus anak2 yg bisa ditangani..sampai KPAI turun tangan bahas anjay...(@ chai.rita/02/09/2020)

(17) Anjay anjay anjay....anjar....daripada bahas kayak gini mending komnas PA bahas yg lbh penting lagi keles tentang bullying,eksploitasi anak hmhmhmhm anjay lah (@bee_dewi/02/09/2020)

Pada data (16), kata anjay digunakan di tengah dan akhir tuturan. Sementara itu, pada data (17), kata anjay digunakan di awal dan akhir tuturan.

Wujud tuturan yang memuat kata anjay dalam komentar warganet di akun @ narasinewsroom menunjukkan bahwa kata anjay sebagai bahasa pergaulan di media sosial Instagram memiliki perilaku yang cukup istimewa. Kata anjay dapat menempati setiap tempat dalam tuturan, baik di awal, di tengah, maupun di akhir.

\section{Nilai Komunikatif Tuturan yang Memuat Kata Anjay dalam Komentar di Akun Instagram @ narasinewsroom}

Komentar yang memuat kata anjay di akun Instagram @narasinewsroom berdasarkan nilai komunikatifnya dapat dibedakan menjadi tuturan deklaratif, tuturan imperatif, tuturan interogatif, tuturan eksklamatif, dan tuturan empatik. Berikut 
tabel tuturan yang memuat kata anjay berdasarkan nilai komunikatifnya.

Tabel 2

Nilai Komunikatif Tuturan yang Menggunakan Kata Anjay

\begin{tabular}{lll}
\hline No & Nilai Komunikatif & $\begin{array}{l}\text { Frekuensi } \\
\text { Kemunculan }\end{array}$ \\
\hline 1 & Tuturan Deklaratif & 14 \\
\hline 2 & Tuturan Interogatif & 23 \\
\hline 3 & Tuturan Imperatif & 19 \\
\hline 4 & Tuturan Eksklamatif & 13 \\
\hline 5 & Tuturan Empatik & 31 \\
\hline
\end{tabular}

1. Tuturan Deklaratif

Tuturan deklaratif (tuturan berita) adalah tuturan yang mengandung maksud memberitakan sesuatu kepada mitra tutur (Rahardi, 2005, p. 74). Kata anjay dalam tuturan deklaratif ini digunakan untuk memberitakan atau mengungkapkan informasi kepada mitra tutur. Berkaitan dengan penggunaan kata anjay dalam tuturan deklaratif, tuturan berikut dapat digunakan sebagai ilustrasi.

(18) Anjayyy hanya pengalihan isu, tetap kawal kebakaran gedung kejaksaan bro 행 (@xhafidhx/02/09/2020)

(19) Dalam bahasa sanksekerta anjay berarti tak terkalahkan (@miftazulfa/02/09/2020)

Data (18) dan (19) mengandung maksud memberitahukan sesuatu. Kata anjay pada data (18) menjadi hal utama yang dibicarakan. Penutur pada data (18) bermaksud memberitahukan bahwa isu-isu tentang kata anjay merupakan pengalihan dari isu lain. Sementara itu, pada data (19), penutur bermaksud memberitahukan kata anjay secara etimologis.

(20) Anjing dan anjay menurut gua berbeda arti sih, anjing sering dipake buat ngata ngatain orang dan udah jelas itu kasar. Sedangkan anjay, itu kaya kita kagum karena sesuatu, kaya "wah" "Mantap". Lagian juga ngapain soal beginian ampe dipidanain sih, gk penting banget bro. (@ mrevkyp/02/09/2020)

(21) Dengan adanya press rilis, secara langsung juga memviralkan dan mengajarkan kata Anjay (2):(@allamin07/02/09/2020)

Tuturan (20) mengandung kata anjay yang digunakan penuturnya untuk memberitahukan pendapatnya terkait dengan penggunaan kata anjay. Pada data (21), kata anjay digunakan dalam tuturan deklaratif yang menyatakan pendapat.

Berdasarkan data-data tersebut, diketahui bahwa kata anjay digunakan dalam tuturan deklaratif. Tuturan dimaksudkan untuk memberitahukan informasi tentang kata anjay.

2. Tuturan Interogatif

Tuturan interogatif adalah tuturan yang mengandung maksud menanyakan sesuatu kepada mitra tutur (Rahardi, 2005, p. 76). Warganet melalui komentarnya bermaksud meminta jawaban dari mitra tuturnya tentang kata anjay yang menjadi pokok pembahasan dalam unggahan yang dikomentari.

(22) Anjay itu sejenis makhluk apa sii... Serius nanya@ ${ }^{-. . . ?}$ (@joeher_/02/09/2020)

(23) Anjay? Anjing naik bajay? cc: @ decdecky (:) (@mellaoi/03/09/2020)

(24) "anjay lu" gaboleh dong? (@ sandratangkulung/03/09/ 2020)

Data (22), (23), dan (24), kata anjay digunakan dalam tuturan yang mengandung maksud menanyakan. Kata anjay pada data (22), (23), (24) 
merupakan hal pokok yang dipertanyakan oleh penutur. Pada data (22), penutur bermaksud menanyakan identifikasi anjay. Tanda tanya merupakan penanda yang menegaskan bahwa data (22) termasuk tuturan interogatif.

Tuturan interogatif yang memuat kata anjay pada data (23) menunjukkan maksud penutur menanyakan anjay sebagai akronim dan kepanjangannya. Penggunaan tanda tanya menjadi penegas bahwa data (23) termasuk dalam tuturan interogatif.

Kata anjay yang digunakan dalam data (24) digunakan penuturnya untuk menanyakan implementasi penggunaan kata anjay dalam berkomunikasi. Penggunaan tanda tanya pada akhir tuturan menjadi ciri yang menandakan bahwa data tersebut termasuk tuturan interogatif.

(25) Kenapa enggak dari duluu dulu dipermasalakan kata Anjay, atau Anjir kanapa baru baru ini. Dan lagi ada lagi kata

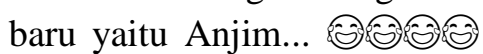
(@ anwaradi92/02/09/2020)

(26) $\mathrm{Yg} \mathrm{gk}$ boleh cuma anjay doang kn.. kalo anjing, anjir, sama anjim brati boleh? (@imantng/02/09/2020)

(27) Mereka terlalu fokus pada "anjay" sehingga tidak memperhatikan para kembarannya seperti anjir, njir, bjir, anjrit, dsb. Kasihan "anjay", dia salah apa sampai disingkirkan? (@wina_alda/02/09/2020)

Data (25), (26), dan (27) termasuk tuturan interogatif yang mengandung kata anjay. Pada data (25), penggunaan kata tanya kapan menjadi penanda bahwa tuturan tersebut termasuk tuturan interogatif yang menjadikan kata anjay sebagai pokok permasalahan yang dipertanyakan. Pada data (26), penggunaan akhiran -kan menjadi penanda bahwa tuturan tersebut disampaikan dengan maksud bertanya tentang penggunaan kata anjay. Data (27) menunjukkan bahwa penutur memperlakukan kata anjay seolah hidup sehingga mempertanyakan perbuatan yang telah dilakukan anjay yang membuat kata tersebut tidak boleh digunakan sebagaimana pernyataan yang dikeluarkan Komnas PA.

Tuturan warganet yang ditulis dalam kolom komentar @ narasinewsroom yang berupa tuturan interogatif ditandai dengan kehadiran tanda tanya (?) dan kata tanya, seperti kenapa, bagaimana, dan apa. Kata anjay menjadi hal utama yang dibicarakan dalam tuturan interogatif yang disampaikan warganet.

3. Tuturan Imperatif

Tuturan imperatif adalah tuturan yang mengandung maksud memerintah atau meminta agar mitra tutur melakukan sesuatu sebagaimana yang diinginkan penutur (Rahardi, 2005, p. 79). Berikut contoh tuturan imperatif dalam komentar warganet di akun Instagram @narasinewsroom yang mengandung kata anjay.

\section{(28) ANJAY TANGKAP AKU (@ajixg/02/09/2020)}

Data (28) adalah tuturan imperatif yang mengandung kata anjay. Melalui data (28), warganet bermaksud memberikan izin kepada mitra tuturnya untuk menangkap dirinya karena menuturkan kata anjay.

(29) Daripada ngomongin kata anjay lebih baik fokus pada kasus pernikahan dibawah 
umur, kekerasan pada anak, eksploitasi anak dsb pak. (@gilar_wu/02/09/2020)

Data (29) menunjukkan tuturan imperatif yang berisi ajakan. Penuturnya (warganet) bermaksud mengajak mitra tuturnya mengubah pokok bahasan dari kata anjay menjadi topik lain tentang permasalahan yang menimpa anak-anak. Penggunaan daripada ... lebih baik menjadi penanda bahwa penutur bermaksud mengajak mitra wicara melalui tuturannya.

(30) salah si seharusnya pelarangan kata yg berimbas negatif(:) bukan cm anjay doang (@nabilaagstia/02/09/2020)

Data (30) juga menunjukkan tuturan imperatif yang mengandung kata anjay dengan maksud mengajak. Penggunaan seharusnya...cuma menjadi penanda keimperatifan tuturan tersebut dengan maksud mengajak.

Tuturan imperatif larangan terdapat pada data (31). Warganet bermaksud menyampaikan kepada mitra tuturnya tentang situasi yang terjadi pada kata anjay. Penutur tidak mempermasalahkan kata anjay yang dilarang untuk digunakan. Penutur menganggap larangan tersebut menjadi penting jika yang dilarang digunakan adalah kata anjas. Tuturan imperatif larangan tersebut ditandai dengan digunakannya kaya jangan. Berikut data (31) yang dimaksud.

(31) Gapapa anjay, yg penting jangan anjas!! Itu nama ku (@dwi.njas/02/09/2020)

Kata anjay ditemukan pada tuturan imperatif dalam komentar warganet di akun Instagram
@ narasinewsroom.

Dalam menyampaikan tuturan imperatifnya, penutur (warganet) menunjukkan maksud yang berbeda, meskipun mengandung kata anjay yang sama.

\section{Tuturan Eksklamatif}

Tuturan eksklamatif adalah tuturan yang dimaksudkan untuk menyatakan rasa kagum (Rahardi, 2005, p. 85). Warganet pengikut akun Instagram @ narasinewsroom dalam komentarnya menyampaikan tuturan yang menunjukkan kekaguman terhadap pokok permasalahan yang disampaikan. Berikut tuturan eksklamatif yang mengandung kata anjay tersebut.

(32) Anjay, sampai dibahas disini juga $\square$ (@k.rfni/02/09/2020)

(33) Anjayyy beritanya, josss dah (2) (@namaku_mohammadyoga/ 02/09/2020)

Data (32) dan (33) menunjukkan tuturan eksklamatif yang mengandung kata anjay. Kata anjay di dalam tuturan pada data-data tersebut selain menjadi pokok tuturan juga sebagai penanda kekaguman penutur. Pada data (32), penutur menunjukkan kekagumannya terhadap unggahan akun Instagram @ narasinewsroom yang berupa video tentang larangan penggunaan kata anjay. Berdasarkan data (33), diketahui juga bahwa kata anjay digunakan sebagai penanda kekaguman dalam suatu tuturan. Pada data (33), warganet menyampaikan kekagumannya terhadap berita yang diunggah @ narasinewsroom.

(34) A N J A Y lu keren dah @lutfiagizal $\quad \square \square \quad$ iyekan @ rizkybillar (@viroada_/02/09/2020) 
(35) @lutfiagizal Babang Poni ANJAY

(@ dwickyzen/02/09/2020)

Data (34) dan (35) menunjukkan tuturan eksklamatif yang ditandai dengan penggunaan kata anjay. Pada data (34), kata anjay ditulis di awal tuturan. Kekaguman dalam tuturan ini ditunjukkan untuk pemilik akun @lutfiagizal. Pemilik akun tersebut merupakan orang yang menolak penggunaan kata anjay dan mengadukan keresahannya tersebut kepada Komnas PA. Penutur yang menuturkan data (35) juga menandai @lutfiagizal dalam tuturannya. Penggunaan kata anjay pada data tersebut juga menunjukkan kekaguman penutur terhadap hal yang dituturkan.

Tuturan eksklamatif yang mengandung kata anjay dalam komentar warganet di akun Instagram @ narasinewsroom menunjukkan karakteristik yang unik. Kekaguman yang disampaikan, selain menunjukkan kekaguman positif, juga dapat menunjukkan kekaguman negatif. Kekaguman positif menunjukkan bahwa penutur melalui tuturannya itu bermaksud memberikan apresiasi dan penghargaan terhadap hal yang dituturkan. Berikut tuturan eksklamatif yang menunjukkan kekaguman positif. Kekaguman positif pada tuturan yang memuat kata anjay terdapat pada data (36) berikut.

\section{(36) Anjaaay ramee} (@mahakarya_azis/03/09/2020)

Sementara itu, kekaguman negatif adalah tuturan yang bertujuan menyampaikan kekaguman, tetapi ada hal berkonotasi negatif di dalamnya. Ada nilai tertentu yang cenderung merendahkan pokok hal yang dituturkan. Data (37) dan (38) berikut mengandung kata anjay dalam tuturan eksklamatif yang menunjukkan kekaguman berkonotasi negatif.

(37) Anjayyyy lebay.. Pansos (@wandydangdang/02/09/2020)

(38) Anjay, sampai dibahas disini juga (r.6) (@k.rfni/02/09/2020)

Pada data (37), penuturnya secara langsung menunjukkan kekaguman berkonotasi negatifnya dengan tuturan yang cenderung negatif. Hal ini dibuktikan dengan munculnya kosakata pergaulan yang lain, yaitu lebay yang artinya 'berlebihan'. Data (38) menunjukkan bahwa penuturnya mengagumi pemberitaan kata anjay yang sampai diberitakan di akun @ narasinewsroom. Melalui tuturan ini, penuturnya seolah ingin menyampaikan bahwa pemberitaan tentang anjay ini sudah menjadi fenomena besar, tetapi sebenarnya tidak cukup penting untuk diberitakan.

5. Tuturan Empatik

Tuturan empatik adalah tuturan yang di dalamnya terkandung maksud memberikan penekanan khusus (Rahardi, 2005, p. 86). Dalam hal ini, kata anjay merupakan kata yang dimaksudkan untuk diberi penekanan. Berikut contoh penggunaan kata anjay dalam tuturan warganet dalam komentar di akun Instagram @ narasinewsroom.

$$
\begin{array}{ll}
\text { (39) } & \text { Anjay! } \\
& (@ \text { bobdudul/02/09/2020) } \\
\text { (40) } & \text { Anjayy } \\
& (@ \text { intanjegeg/02/09/2020) }
\end{array} \text { lah }
$$

Data (39) dan (40) dituturkan sebagai tuturan empatik. Penggunaan kata anjay yang diikuti tanda seru pada data (39) dan akhiran lah pada data (40) menjadi penegas bahwa tuturan tersebut menjadikan kata anjay sebagai pokok 
tuturan empatik. Hal yang ditekankan dari kedua tuturan tersebut adalah kata anjay itu sendiri. Tuturan jenis ini dapat berada dalam kisaran tuturan empatik yang sangat halus hingga sangat kasar. Keberadaan kata anjay tidak dapat dijadikan sebagai penanda halus atau tidaknya tuturan empatik pada data (39) dan (40).

(41) Alah bikin peraturan yg apa2 tujuan nya cuman nguras duit,,,makan tu anjay (@jepry666/03/09/2020)

Data (41) merupakan tuturan empatik yang mengandung kata anjay dengan alah sebagai penandanya. Melalui data (41), penutur bermaksud memberikan penekanan khusus terhadap peraturan yang dalam hal ini tentang penggunaan kata anjay. Data (41) ini dikategorikan sebagai tuturan empatik yang cukup halus.

Komentar yang dituturkan warganet dalam kolom komentar di akun Instagram @ narasinewsroom yang memuat kata anjay menunjukkan wujud tuturan yang beragam. Berdasarkan posisi dan nilai komunikatifnya, kata anjay berpotensi menunjukkan perilaku tertentu. Kata anjay memiliki potensi untuk digunakan dalam beragam tuturan dengan nilai komunikatif yang berbeda. Posisi kata anjay dalam tuturan turut memengaruhi nilai komunikatif kata tersebut.

\section{PENUTUP}

Komentar yang dituturkan warganet atau pengguna media sosial sangat beragam. Kata anjay yang menjadi perbincangan pun tidak luput dari komentar warganet. Apalagi, akun Instagram @narasinewsroom mengunggah konten yang berupa video singkat tentang larangan penggunaan kata anjay tersebut.
Setelah dianalisis, realisasi penggunaan kata anjay dalam tuturan yang disampaikan warganet dalam komentar di akun@Instagram @narasinewsroom menunjukkan karakteristik yang beragam. Berdasarkan wujudnya, posisi kata anjay ditemukan terletak di empat posisi, yaitu di awal tuturan; di tengah tuturan; di akhir tuturan; dan gabungan antara di awal, tengah, dan akhir. Sementara itu, berdasarkan nilai komunikatifnya, tuturan yang memuat kata anjay dalam komentar warganet di akun Instagram @ narasinewsroom menunjukkan lima nilai tuturan, yaitu tuturan deskriptif, tuturan interogatif, tuturan imperatif, tuturan eksklamatif, dan tuturan empatik.

Posisi kata anjay dalam tuturan memengaruhi nilai komunikatif tuturan tersebut. Meskipun demikian, tidak selalu nilai komunikatif tuturan yang memuat kata anjay mengandung makna negatif. Anjay sering kali digunakan sebagai ungkapan (ekspresi) bentuk kekaguman terhadap sesuatu yang dalam hal ini pemberitaan tentang larangan penggunaan kata anjay itu sendiri. Fenomena penggunaan kata anjay ini dapat menjadi bukti bahwa bahasa terus mengalami perkembangan seiring dengan perkembangan penuturnya. Teknologi yang semakin maju pun turut memengaruhi bahasa, khususnya bahasa ragam pergaulan.

\section{DAFTAR PUSTAKA}

Cummings, L. (2007). Pagmatik Sebuah Perspektif Multidisipliner. Yogyakarta: Pustaka Pelajar.

Djajasudarma, T. F. (2009). Metode Linguistik: Ancangan Metode Penelitian dan Kajian. Bandung: PT Eresco.

Husa, S. M. (2017). Bentuk dan Pemakaian Slang pada Media Sosial Line (Akun Batavia Undip). Universitas Diponegoro.

Khoirurrohman, T. \& Abdan, M. R. (2020). Analisis Pemakaian Variasi Bahasa Slang pada Remaja Desa Kalinusu: 
Kajian Sosiolinguistik. Jurnal Semantika, 1(02), 1-11. Diakses dari http://jurnal.umus.ac.id/index.php/sem antika/article/view/165/101.

Kusmanto, Hari, dkk. (2019). Realisasi Tindak Kesantunan Berahasa pada Komentar Akun Instagram Jokowi: Studi Politikopragmatik. Kandai, 15(1), 47-60.

Listeani, F. Y. (2020). Penggunaan Kosakata Bahasa Indonesia pada Generasi Millenial. Basastra, 9(1), 115. Diakses dari https://jurnal.unimed.ac.id/2012/index. php/basastra/article/view/17771.

Mahsun. (2017). Metode Penelitian Bahasa: Tahapan, Strategi, Metode, dan Tekniknya. Jakarta: Raja Grafindo Persada.

Nurlina, Wi. E. S. (2019). Tindak Tutur pada Nasihat Berbahasa Jawa yang Berkonjungsi Yen. Widyaparwa, 47(2), 33-43.

Rahardi, R. K. (2005). Pragmatik: Kesantunan Imperatif Bahasa Indonesia. Jakarta: Erlangga.

Setyawati, N. (2014). Pemakaian Bahasa Gaul dalam Komunikasi di Jejaring Sosial. Sasindo, 2(2). Diakses dari http://103.98.176.9/index.php/sasindo/ article/view/974/892.

Sudaryanto. (2015). Metode dan Aneka Teknik Analisis Bahasa: Pengantar Penelitian Wahana Kebudayaan Secara Linguistik. Yogyakarta: Sanata Darma University Press. 